\title{
A Contrastive Study on Semantics of National Culture in Chinese and English Animal Words
}

\author{
Chen Juan ${ }^{1}$, zhong Liangji ${ }^{2}$ \\ 1School of Foreign Language, Xianning Vocational\& Technical College, Hubei437100, China; \\ 2 Hubei science and Technology Institute, China
}

Keywords: semantics: national; animal words.

\begin{abstract}
The concept of national cultural semantics is a cultural aspect of semantics, also an embodiment of national culture and custom. Living in the same nature with Man, animals contain abundant national emotion, culture and customs. The same animal words, in their prolonged course of history and due to the influence of the following factors: historical and cultural backgrounds, religious beliefs and geographical surroundings, have formed their own national traits, so in different cultures, the certain animal word will arouse different emotions.
\end{abstract}

\section{Introduction}

We can have different meanings of the same word. All people, drawing on their backgrounds decide what a word means(Yang Yuangang). The concept of national cultural semantics is a cultural aspect of semantics, also an embodiment of national culture and custom. Living in the same nature with Man, animals contain abundant national emotion, culture and customs. The same animal words, in their pro longed course of history and due to the influence of the following factors: historical and cultural backgrounds, religious beliefs and geographical surroundings, have formed their own national traits, so in different cultures, the certain animal word will arouse different emotions. For example, owl in Chinese culture is associated with adversity, but wisdom in English. There are many other examples, evil bat and auspicious bianfu, loathsome magpie and happy xique. This essay bases on plentiful language materials to explore national cultural semantics as shown in these animals and Make a contrastive study between Chinese and English.

\section{Dragon and "Long"}

In the English-Chinese dictionary the corresponding word of "Long" in English is dragon. In both cultures, it is an animal that only existed in the imaginary world. These images that the two cultures give are wholly different.

2.1 The cultural meaning of "Long"

In traditional Chinese culture, "Long" is considered as a marvelous animal. There is a worship phenomenon that has covered most of the country for thousands of years. Since "Long" has excellent ability in Chinese's eyes, it is also a symbol of emperor and royalty. It seems that anything related to the emperor has a connection with "Long". The emperor's bed is called as dragon bed and his clothes are called as dragon clothes. The looks are called as dragon looks. In traditional myth, "Long" is also the god of thunder, rain, rainbow and star. There are many Chinese idioms about "Long". "Longfeifengwu" (dragon flying and phoenixes dancing) means "lively and vigorous flourishes in calligraphy". "Longtenghuyue" (dragon rising and tigers leaping) mean "a scene of hustling activity".

2.2 The cultural meaning of dragon

According to the Webster's Ninth New Collegiate Dictionary, dragon is a huge serpent or a mythical animal represented as a monstrous winged and scaly serpent or saurian with a crested head and enormous claw. "Dragon's teeth" means "seeds of strife", because in Roman myth the dragon's teeth are sown by Cadmus who sprang up as armed warriors that killed one another off. In Christian art, a dragon is a symbol of sin. It is often represented as crushed under the feet of saints or being 
killed by them, symbolizing the triumph of Christianity over paganism. Many European legends tell how a hero killed a dragon. For example, St.George, the patron saint of England, has rescued a princess from a dragon and killed it. In The Revelation, The New Testment, it records a story named "the woman and the dragon". The description is like "a great red dragon with seven heads and ten horns and seven diadems on his head. His tail swept down a third of the stars of heaven and to the earth and then the dragon stood before a woman who was about to bear a child, so that he might devour her child as soon as it was born". Also in this story, "the dragon and his angels fought back, but they were defeated, and there was no longer any place for them in heaven. The great dragon was thrown down, that ancient serpent, who is called the Devil and Satan, the deceiver of the whole world-he was thrown down to the earth".

2.3 The reason why these differences exist

It seems that the dragon's fierceness has nothing to do with the sanctity of "Long". There are many records about "Long" in Chinese traditional classics. The image of "Long" is glorious. According to Chinese myth, "Long" is the god of rain. The notion that "Long" could bring rain is deeply rooted in common Chinese's heart. As well known, china is a country that depends on agriculture, so the importance of rain is obvious. Thence "Long" becomes the target of sacrifice. Since Qinshihuang, the famous emperor who united china, "Long" was an incarnation of emperor.

In the Long feudal history, the lofty position "Long" has in religion and mysterious connection with royalty Made he enjoy a wide popularity in China. But there is another picture in western world, dragon can be found in Bible and Greece myth, but they just show its cruelty. In myth, dragon is often considered as a protector of a great treasury, or a robber who plundered the princess. In Bible, the great western classics, just like "Long" and the emperor, dragon has untold relation with Devil. This is an interesting fact. The two different cultures bring up different "Long" and dragon.

\section{Dog and "Gou"}

whether in eastern or western world, dog is a familiar animal. Since its domestication in early times, dog can't be departed from people's daily life. Dog can help people hunt, guard the house and catch thieves. People even keep a dog as a pet. In the history of literature, there are many story talk about dog's loyalty. But in essence, two cultures take very different views to dog.

3.1 the cultural meaning of "Gou"

Dog is a common animal. In some folk legends, it wins people's heart by its faithfulness and agility. There is a Chinese saying "the child like his mother though she is plain, the dog loyal to its master though he is poor". There is a moving story about a dog. Lu Ji was a literary Man in Wei dynasty, and he once owned a dog called "yellow year". One time Lu Ji had some emergency to tell his family members, but he couldn't find a reliable messenger, so he sent "yellow year" to do the job. He also asked the dog to take a reply. As fifty days passed, "yellow year" returned with the reply. But the dog was so tired that it died. Lu Ji cried for his dog and built it a tomb. But in general, people often associate contemptibility and humbleness with a dog. If a person is called a dog, that's really an insult. In Chinese culture, dog is totally bad, even the words that contain dog are derogatory. For example, GoutoujunShi (dog-headed counselor) refer to "a person who offers bad advice". Gouyankanrendi means "be dammed snobbish". GouGouyingying means "ingratiate oneself with sb. to gain one's ends". Dog is really a distastefulness in Chinese traditional culture.

\subsection{The cultural meaning of dog}

Madame Roland (1754-1793), a famous figure in the France revolution had said: "the more I see of Man, the more I admire dogs." The sentence shows westerners' liking for dog. In Western society, dog is men's best friend. In English, dog also refers to people, but it is a big difference with Chinese dog. For example, "a lucky dog", "an old dog", "a jolly dog","a dumb dog", which all refer to people without any insult. The person who is called a dog feels no angry. In westerner's eyes, dog is equal to people at some extent. Many people treat dog as their family member. Some moving story about dog is popular in society such as "infant and his dog", "the status of the dog". There are also many places provide services to dog, include shop, restaurants, hospital and hotel. Some people even build stale and tomb for their dogs. According to investigation of CHOICE, a British magazine, $10 \%$ people 
think that dog can bring them more happiness than their companion. $20 \%$ prefer dog to their own child and 50\% put dog ahead of their job. Though dog enjoys warm welcome in western world, it has another face. It is the symbol of dirty habits. "Be going to the dogs" means "things get much worse and will be difficult to improve". "Dog's life " refers to a life full of hard work and worry. "To say something is a dog" means "somethings is very poor in quality". The abominable image way comes from Bible and Aseop's fables. In the story "the coming of Jesus" from THE REVELATION, THE NEW TESTMENT, dog can't get in by the gate. "Outside are the dogs and sorcerers and fornicators and murderers and idolaters and who loves and practices falsehood". In Aseop's fables, there are several stories about dogs. In the story "the dog in the manger", the dog sleeps in the manger where the horse's food is kept. When the horse comes up to eat their evening meal the dog spring up, snarling and snapping. In this story, dog is very selfish.

3.3 The reason why these differences exist

Both in Chinese and Western culture, dog played a double role. But in Chinese culture dog took more negative quality while in western culture, the bad images can't cover the luster of dog. The first reason is the different family value. In western culture, individualism is the pursuit. When the child grown up, they leave their parents to live an independent life. So many old people are alone at home. they need something to fill the blankness. Then dog with the nature become the first choices. While in China, old people often live with the young; their life May be filled with their grandchildren.

Western parents often make their children to take care of animals like dog to foster the sense of responsibility. Chinese don't do this. The other reason is the different values towards life. Western culture is self-centered, dog win people's heart by the faithfulness and allegiance. While Chinese culture embraces harmony. Dog's faithfulness is sometimes considered as toadyism. From history view, in old China, dog is often guard at the gate of officer and moneybag. They use dog as a tool to frighten the common people. The oppressed people regard the officer and moneybag with hostility, then they transfer the dislike to dog, dog is considered as the accomplice.

\section{$4 \mathrm{Shi} /$ lion and $\mathrm{Hu} /$ tiger}

Lion and tiger are both fierce beasts. They lived in the wild nature. To some extent, they are stronger than human. Both of them enjoy high prestige in the animal world.

4.1 The cultural meaning of $\mathrm{Hu}$ and tiger

In Chinese culture, tiger is the king of beasts. Sturdiness and braveness are the outstanding characteristics. Tiger often associate with power. A tiger banner shows the government's stateliness. A man who is "tiger-backed and bear-voined" is very powerful. In traditional myth, tiger is also the magical animal that could eat the demon. But tiger at the same time mean outrage and cruelty. Man eaten by tiger was not news in old times. So tiger is also associated with horror, dangerous places are called as "tiger's mouth" or "tiger's den". To do a very dangerous thing is to "pull off teeth from tiger's mouth". The most famous story is "Wu Song strives the tiger" Since he put the tiger to death by his own strength, he was considered as a great hero. But tiger in English don't have so many cultural meanings. In English, tiger is a fierce and bloodthirsty person or quality, a vigorously aggressive person. Fierceness is the only quality associated with it. For example, "arouse the tiger in somebody's nature" is to stimulate his brutality. English idioms "paper tiger" and "ride on the tiger" both come from China. In English, people use "blind tiger" to refer a place where alcoholic drinks are sold illegally. Tiger is a kind of gamble. According to Walsh, the usage could date back to China. He thinks in traditional Chinese culture, tiger is a symbol of lucky, so tiger's pictures were hanged at the gate of gambling house. Actually, the national cultural meaning of tiger in English is just a part of that in Chinese and most of them are originate from China.

4.2 The cultural meaning of Shi and lion

There are few words related to lion in Chinese culture, and most of them come from foreign culture such as the Buddhist Scriptures. But, stone lions made by Chinese are really works of art. The most outstanding is the stone lions of LuGou Bridge. In tradition, there are status of lions placed at the gate of imperial palaces, official residents, temples and tombs. Incense burners and imperial seal were decorated with carved lions. Chinese think that lion can provide protection; it could drive the evil 
spirits away. In Chinese there is only one idiom about lion. That is "hedongShihou" ( the lioness from Hedong prefecture roars ). The idiom originated from SuShi, he had written a poem that employed the idiom to joke his friend Chenzao. In English, lion has many cultural meanings. According to dictionary, lion could refer to a person who is outstanding or very important. Lion is also key points of interest, because it is said that anyone who comes to London would see the lions of the London tower. Lion is the symbol of England. Shelly had written a poem, call his people to "rise like lion after slumber". The story about lion is also found in Aesop's Fables. In the story "the lion and the bull", the lion show his witness. In anther story "Androcles and the lion", the lion shows his gratitude. People also use "the kingdom of lion" to refer to the wise king. In Hemingway's Masterpiece The old man and the sea, Santiago, the iron-willed hero, at the end dreamed a lion. The lion is the incarnation of courage. English idioms "regal as a lion" and "majestic as a lion" also show that the position lion has in western world.

4.3 The reason why these differences exist

Tiger and lion, the king of beast in Chinese and western culture, enjoy the renown in different cultures. Why do Chinese prefer tiger while westerner prefer lion? It is caused by the geographical conditions. Tiger is only living in Africa and Eastern Asia. Lion is living in Africa and Southern Asia. "a lion in the way" and "dangluhu", "beard the lion" and "nühuxu", "place oneself in the lion' $\mathrm{s}$ mouth" and "zhishenhukou". Those idioms show that tiger and lion are corresponded in some way.

\section{Summmary}

The paper reveals different national cultural meanings of some animal words both in Chinese and English and explores the cultural sources behind the words. It is a great help to understand and translate between Chinese and English and also benefit the inter-culture exchanges. As the development of communication between cultures, there is a phenomenon called the mixture of culture. In future study, we should pay more attention to this problem and try to find a balance and accommodation.

\section{References}

[1] J. van der Geer, J.A.J. Hanraads, R.A. Lupton, The art of writing a scientific article, J. Sci. Commun. 163 (2000) 51-59.

Reference to a book:

[2] W. Strunk Jr., E.B. White, The Elements of Style, third ed., Macmillan, New York, 1979. Reference to a chapter in an edited book:

[3] G.R. Mettam, L.B. Adams, How to prepare an electronic version of your article, in: B.S. Jones, R.Z. Smith (Eds.), Introduction to the Electronic Age, E-Publishing Inc., New York, 1999, pp. 281-304.

[4] R.J. Ong, J.T. Dawley and P.G. Clem: submitted to Journal of Materials Research (2003)

[5] P.G. Clem, M. Rodriguez, J.A. Voigt and C.S. Ashley, U.S. Patent 6,231,666. (2001) 